\title{
UPAYA PENINGKATAN KEAKTIFAN BELAJAR PESERTA DIDIK DENGAN PENDEKATAN DISCOVERY LEARNING MENGGUNAKAN GOOGLE CLASSROOM
}

\author{
Oleh: \\ Retno Puji Purwati ${ }^{1}$
}

\begin{abstract}
Abstrak
Rendahnya keaktifan belajar peserta didik pada masa pandemic merupakan masalah serius yang harus ditangani. Penelitian ini bertujuan untuk mengetahui apakah model pembelajaran discovery learning dapat meningkatkan keaktifan belajar peserta didik. Jenis penelitian ini adalah penelitian tindakan kelas (PTK) dengan prosedur persiklus yang terdiri dari kegiatan perencanaan, pelaksanaan, observasi dan pengamatan. Subjek penelitian ini adalah peserta didik kelas XI IPS SMA Negeri 2 Kroya yang berjumlah 24 peserta didik. Teknik pengumpulan data yang digunakan adalah menggunakan observasi dan wawancara. Dari hasil penelitian pada tahap pra siklus ditemui tingkat keaktifan peserta didik sebesar 55,95\%. Kemudian meningkat pada siklus I menjadi $64,06 \%$ dan pada siklus II 76,38\%. Kesimpulan dari penelitian ini adalah terjadi peningkatan keaktifan belajar peserta didik dengan menggunakan model pembelajaran discovery learning.
\end{abstract}

Kata Kunci : Keaktifan belajar, discovery learning, google classroom

\footnotetext{
${ }^{1}$ Guru Sosiologi di SMA Negeri 2 Kroya, email : retnoyudhist@gmail.com
} 


\section{Pendahuluan}

Pendidikan memegang peran penting dalam upaya meningkatkan taraf hidup bangsa Indonesia agar tidak tertinggal dengan negara lain. Sebagaimana tercantum dalam UU No. 20 Tahun 2003 Pasal 3. Di era globalisasi saat ini pendidikan menjadi kebutuhan utama, karena hanya melalui pendidikan kita mampu menjawab tantangan kehidupan yang semakin kompleks di segala bidang. Upaya peningkatan kualitas pendidikan para peserta didik disetiap tingkat pendidikan perlu diwujudkan agar memperoleh kualitas sumber daya manusia Indonesia yang dapat menunjang pembangunan Nasional. Upaya untuk meningkatkan kualitas pendidikan dipengaruhi oleh kurikulum, buku pembelajaran, media pembelajaran, model pengajaran. Pembenahan model pembelajaran selalu dilakukan dengan mencari model pembelajaran yang tepat sesuai dengan bahan ajar.

Namun kenyataannya, mayoritas peserta didik cenderung tidak responsif dalam kegiatan pembelajaran jarak jauh (PJJ). Hal ini ditandai dengan peserta didik cenderung diam saat diajak berinteraksi, peserta didik tidak memiliki inisiatif sendiri untuk mencatat pelajaran yang disampaikan, peserta didik kurang berani menyatakan pendapat, terbukti ketika diberi pertanyaan peserta didik cenderung diam dan tidak memberikan respon. Sehingga aktivitas peserta didik pada saat proses pembelajaran perlu diperhatikan oleh guru, agar proses belajar mengajar yang ditempuh mendapatkan hasil yang maksimal. Namun tentunya guru juga memiliki batasan, dimana guru tidak dapat memperhatikan peserta didiknya satu persatu.

Maka dari itu guru perlu mencari solusi untuk meningkatkan keaktifan peserta didik agar proses pembelajaran tidak bersifat satu arah saja. Karena jika keaktifan belajar dari peserta didik rendah maka berdampak pada terpusatnya proses pembelajaran pada guru. Guru memiliki peran yang lebih besar dibandingkan dengan peserta didik dalam proses pembelajaran. Hal ini berakibat pada ilmu atau informasi yang didapat oleh peserta didik hanya bersumber dari guru saja sehingga peserta didik tidak memperoleh ilmu yang lebih luas atau beragam. Hal ini tidak sesuai dengan prinsip Kurikulum Nasional, dimana peserta didik dituntut untuk aktif, sedangkan guru hanya bersifat sebagai fasilitator saja. Guru harus menyediakan sumber dan media belajar yang sesuai dan beragam dalam 
setiap kegiatan pembelajaran, dan tidak menjadikan dirinya sebagai satu satunya sumber belajar bagi para peserta didik. Apabila prinsip Kurikulum Nasional dapat dilaksanakan dengan baik, tentunya akan diikuti dengan kemandirian belajar peserta didik yang ikut menjadi baik.

Namun faktanya, keaktifan belajar peserta didik saat proses pembelajaran masih relatif rendah. Masih terdapat peserta didik yang kurang kesadarannya dalam mempersiapkan diri sebelum proses belajar mengajar dimulai. Hal ini dilihat ketika guru memulai kegiatan belajar mengajar, hanya sebagian peserta didik yang sudah siap untuk mengikuti pembelajaran. Saat diberikan tugas, peserta didik tidak langsung mengerjakan namun masih bergantung pada temannya, misalnya apabila diberi latihan soal masih menunggu jawaban dari temannya. Kurangnya rasa tanggung jawab peserta didik dalam pengumpulan tugas, dilihat pada saat mengumpulkan tugas. Peserta didik akan mengumpulkan tugas hanya setelah guru memerintah. Ini berarti bahwa kemandirian belajar yang rendah, kemungkinan memberikan dampak pada ketidakberhasilan proses belajar atau rendahnya prestasi belajar.

Melihat data yang ada disekolah kami selama masa pandemic beberapa bulan terakhir ini, keaktifan peserta didik dalam mengikuti pembelajaran jarak jauh (PJJ) masih tergolong rendah. Saya ambil contoh untuk pembelajaran sosiologi di kelas XI IPS, persentasi keaktifan belajar peserta didik masih rendah. Peserta didik cenderung pasif, dimungkinkan karena merasa bahwa gurunya tidak mengamati. Kondisi seperti ini memaksa guru harus mampu menerapkan strategi pelajaran yang tepat agar peserta didik secara aktif dapat tetap mengembangkan potensi yang dimilikinya meski pembelajaran daring.

Berdasarkan fakta dan data diatas, dapat dikatakan bahwa ada masalah dengan keaktifan belajar peserta didik selama pandemic. Salah satu upaya yang dapat dilakukan untuk meningkatkan keaktifan belajar peserta didik adalah dengan menerapkan model pembelajaran yang sesuai. Berhubungan dengan hal tesebut, peneliti memilih untuk menggunakan model pembelajaran discovery 
learning. Hal ini karena menurut peneliti, dengan melibatkan peserta didik dalam proses penemuan maka pengalaman belajar peserta didik menjadi kuat dan menuntuk peserta didik untuk aktif dalam proses penemuan.

Keaktifan memiliki beberapa definisi, menurut Rusman (2014: 101): "Keaktifan dapat berupa kegiatan fisik dan psikis. Kegiatan fisik dapat berupa membaca, mendengar, menulis, berlatih keterampilan-keterampilan dan sebagainya. Sedangkan kegiatan psikis misalnya menggunakan khasanah pengetahuan yang dimiliki dalam memecahkan masalah yang dihadapi, membandingkan satu konsep dengan yang lain, menyimpulkan hasil percobaan dan kegiatan psikis yang lain".

Sardiman (2011: 100) menyatakan bahwa "Keaktifan merupakan kegiatan yang meliputi fisik dan mental, berbuat (fisik) dan berfikir (mental) merupakan suatu kegiatan yang tidak dapat dipisahkan.” Sebagai contoh seorang peserta didik belajar dengan cara membaca. Secara fisik terlihat bahwa peserta didik membaca menghadapi suatu buku, namun mungkin saja pikirannya tidak tertuju pada buku yang dibacanya. Definisi tersebut juga didukung oleh Dimyati (2009: 114) yang menyatakan bahwa "Keaktifan siswa dalam pembelajaran mengambil beraneka kegiatan dari kegiatan fisik hingga kegiatan psikis, artinya kegiatan belajar melibatkan aktivitas jasmaniah maupun aktivitas moral". Selanjutnya, Saefuddin dan Ika Budiarti (2014: 5758) menyebutkan bahwa salah satu kelebihan Model Pembelajaran Discovery Learning adalah “(7). Berpusat pada peserta didik dan guru berperan sama-sama aktif mengeluarkan gagasan-gagasan. Bahkan guru dapat bertindak sebagai peserta didik dan sebagai peneliti di dalam situasi diskusi”.

Berdasarkan pendapat dari beberapa para ahli diatas, maka dapat ditarik kesimpulan bahwa keaktifan belajar merupakan segala usaha peserta didik dengan melakukan kegiatan secara fisik meliputi membaca, mendengar, menulis, berlatih keterampilan dan sebagainya. Sedangkan psikis lebih cenderung pada proses berpikir dalam upaya memperoleh pengalaman dalam belajar agar proses belajar dapat dikatakan berhasil. Pembelajaran yang dilakukan antara guru dan peserta didik, seharusnya mengacu pada peningkatan aktivitas dan partisipasi peserta didik. Guru tidak hanya menyampaikan 
pengetahuan, keterampilan, dan sikap kepada peserta didik, akan tetapi guru juga harus mampu membawa peserta didik untuk aktif dalam berbagai bentuk belajar berupa belajar penemuan, belajar mandiri, belajar berkelompok, belajar memecahkan masalah, dan sebagainya.

\section{Metode Penelitian}

Penelitian ini termasuk kedalam jenis penelitian tindakan kelas (PTK). Penelitian ini dilakukan di SMA Negeri 2 Kroya Tahun Ajaran 2020/ 2021 pada kelas XI IPS, dengan jumlah peserta didik sebanyak 24 peserta didik. Penelitian ini dilaksanakan pada saat situasi pandemic sehingga penelitian dilakukan dengan menggunakan moda daring, dengan memanfaatkan whatsapp group dan google classroom sebagai media pengganti kelas konvensional.

Metode pengumpulan data yang digunakan dalam penelitian ini adalah dengan melakukan observasi dan juga wawancara. Teknik observasi dilakukan untuk mengukur keaktifan peserta didik ketika pembelajaran, sedangkan wawancara dilakukan untuk memperkuat data. Wawancara dilakukan terhadap peserta didik untuk mengetahui respon peserta didik terhadap penggunaan model discovery learning.

Penelitian ini dilakukan dengan model siklus. Dalam setiap siklus terdapat 4 kegiatan, yaitu perencanaan, pelaksanaan, observasi dan refleksi. Penelitian Tindakan Kelas (PTK) ini dimaksudkan untuk meningkatkan keaktifan belajar peserta didik kelas XI IPS SMA Negeri 2 Kroya dengan mengimplementasikan model pembelajaran Discovery Learning. Indikator tercapainya keberhasilan dari penelitian ini adalah tercapainya persentase keaktifan belajar peserta didik minimal sebesar 70\%. Angka indikator keberhasilan minimal ini didasarkan kepada pedoman konversi keaktifan belajar bahwa angka $70 \%$ tersebut mencerminkan kualitas dari keaktifan belajar peserta didik berada pada kriteria "baik". Cara mengukurnya adalah dengan melakukan observasi pada saat pembelajaran dengan menggunakan lembar observasi dengan mengunakan 3 kriteria keaktifan belajar peserta didik, yaitu (1) keaktifan menanya dan menyampaikan pertanyaan, memperhatikan apa yang disampaikan 
guru, (3) mengerjakan tugas dengan kemampuan sendiri

Tabel Pedoman konversi keaktifan belajar peserta didik

\begin{tabular}{|c|c|}
\hline Tingkat Persentase & Kriteria \\
\hline $80 \%-100 \%$ & Sangat Baik \\
\hline $70 \%-79 \%$ & Baik \\
\hline $60 \%-69 \%$ & Cukup \\
\hline $50 \%-59 \%$ & Kurang \\
\hline $0 \%-49 \%$ & Sangat Kurang \\
\hline
\end{tabular}

Data keaktifan belajar peserta

didik yang merupakan data kuantitatif yang menunjukan penilaian atas keaktifan belajar dari peserta didik berdasarkan kemunculan indikatorindikator dari keaktifan belajar. Skor setiap pernyataan dijumlahkan dan dibagi dengan skor maksimal seluruh pernyataan. Kemudian untuk memperoleh persentase skor keaktifan belajaar, hasil hitung sebelumnya dikalikan dengan $100 \%$.

Keaktifan peserta didik $=\frac{\text { jumlah indikator yang muncul }}{\text { jumlah maksimal indikator }} \times 100 \%$ Setelah data persentase skor keaktifan belajar diperoleh, maka dapat dibandingkan hasil dari rata-rata persentase skor keaktifan belajar antar siklus. Sehingga dapat diperoleh data perubahan keaktifan belajar peserta didik setiap siklusnya, dan dapat diketahui apakah tingkatan keaktifan belajar peserta didik terdapat perubahan atau tidak.

Sedangkan data kualitatif dalam penelitian ini dianalisis menggunakan analisis data kualitatif yaitu analisis data yang peroleh bentuk kalimat dan aktifitas peserta didik dan guru. Analisis data ini dilakukan sejak pengumpulan data dan dikerjakan secara intensif yaitu sesudah meninggalkan lapangan. Menurut Arikunto (2010: 246), “aktifitas dalam analisis data yaitu reduksi data (data reduction), penyajian data (data display), dan penarikan kesimpulan/ verifikasi data (conclusion drawing/ verification)".

\section{Hasil dan Pembahasan}

\section{Pra Siklus}

Penelitian ini dimulai dari kegiatan pra siklus. Tahap pra siklus adalah tahap dimana belum diterapkannya model pembelajaran yang baru. Tujuannya adalah untuk mengetahui seberapa jauh keaktifan dan kemampuan peserta didik dalam pembelajaran sosiologi dikelas sebelum diterapkannya model pembelajaran discovery learning. Tahap pra siklus ini dilaksanakan pada pembelajaran jarak jauh hari senin tanggal 12 Oktober 2020 pada materi 
Masalah Sosial. Dalam kegiatan pra siklus diperoleh data sebagai berikut :

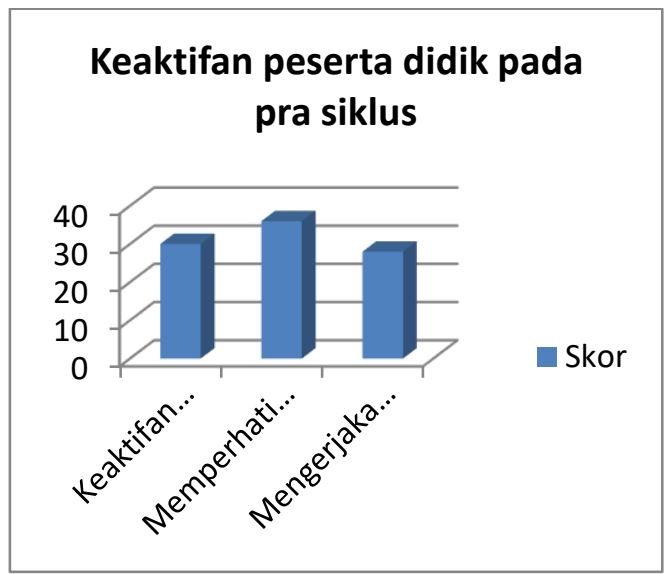

Data tersebut dapat kita jabarkan menjadi :

\begin{tabular}{|l|l|c|}
\hline No & \multicolumn{1}{|c|}{ Aspek yang diamati } & Score \\
\hline 1 & $\begin{array}{l}\text { Keaktifan menanya dan } \\
\text { menyampaikan pendapat }\end{array}$ & 30 \\
\hline 2 & $\begin{array}{l}\text { Memperhatikan apa yang } \\
\text { disampaikan guru }\end{array}$ & 36 \\
\hline 3 & $\begin{array}{l}\text { Mengerjakan tugas } \\
\text { dengan kemampuan } \\
\text { sendiri }\end{array}$ & 28 \\
\hline & $\begin{array}{l}\text { Jumlah scor yang muncul } \\
\text { Dari 24 peserta didik yang }\end{array}$ \\
\hline
\end{tabular}

mengikuti pembelajaran sebanyak 14 peserta didik. Jumlah maksimal indicator adalah 3 indikator x 4 (skor maksimal) x 14 peserta didik $=168$. Dari table diatas, terdapat sebanyak 94 indikator yang muncul, sehingga dapat dihitung persentase keaktifan peserta didik sebagai berikut :
Keaktifan peserta didik $=\frac{\text { jumlah indikator yang muncul }}{\text { jumlah maksimal indikator }} \times 100 \%$ Keaktifan peserta didik $=\frac{94}{168} \times 100 \%$ Keaktifan peserta didik $=55,95 \%$ Hasil tersebut memberikan gambaran bahwa keaktifan belajar peserta didik (pra siklus) kelas XI IPS SMA Negeri 2 Kroya tidak maksimal atau masih rendah/ kurang. Berdasarkan hasil refleksi terhadap rendahnya keaktifan belajar peserta didik di kelas tersebut, kemudian peneliti membuat perencanaan tindakan dalam penelitian tindakan kelas pada siklus I, yaitu menerapkan pembelajaran dengan menggunakan model pembelajaran discovery learning.

\section{Siklus I}

Siklus 1 dilaksanakan pada hari Kamis, 22 Oktober 2020 di kelas XI IPS SMA Negeri 2 Kroya dengan jumlah peserta didik sebanyak 24. Materi yang disampaikan pada siklus 1 adalah diferensiasi social. Langkahlangkah dalam siklus I dimulai dari perencanaan, pelaksanaan, pengamatan dan refleksi. Hasil dari siklus 1 adalah sebagai berikut : 


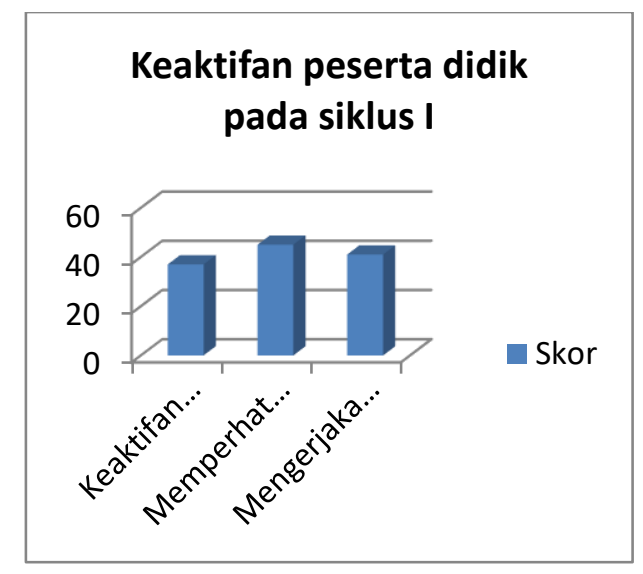

Data tersebut dapat kita jabarkan menjadi :

\begin{tabular}{|l|l|c|}
\hline No & \multicolumn{1}{|c|}{ Aspek yang diamati } & Score \\
\hline 1 & $\begin{array}{l}\text { Keaktifan menanya dan } \\
\text { menyampaikan pendapat }\end{array}$ & 37 \\
\hline 2 & $\begin{array}{l}\text { Memperhatikan apa yang } \\
\text { disampaikan guru }\end{array}$ & 45 \\
\hline 3 & $\begin{array}{l}\text { Mengerjakan tugas } \\
\text { dengan kemampuan } \\
\text { sendiri }\end{array}$ & 41 \\
\hline & \begin{tabular}{l} 
Jumlah scor yang muncul \\
\hline
\end{tabular}
\end{tabular}

Dari 24 peserta didik, yang mengikuti pembelajaran sebanyak 24 anak. Ini berarti bahwa pembelajaran hari ini diikuti oleh semua peserta didik kelas XI IPS SMA Negeri 2 Kroya. Jumlah maksimal indicator adalah 3 indikator x 4 (skor maksimal) x 24 peserta didik $=288$

Dari tabel diatas, terdapat sebanyak 123 indikator yang muncul dari 192, sehingga dapat dihitung persentase keaktifan peserta didik sebagai berikut:
Keaktifan peserta didik

$=\frac{\text { jumlah indikator yang muncul }}{\text { jumlah maksimal indikator }} \times 100 \%$

Keaktifan peserta didik $=\frac{123}{192} \times 100 \%$

Keaktifan peserta didik $=64,06 \%$

Dari perhitungan diatas, kita dapat melihat bahwa persentase keaktifan peserta didik mengalami kenaikan dibandingkan ketika pra siklus. Keaktifan peserta didik pada siklus I adalah sebesar 64,06\%. Namun, hal ini menunjukkan keaktifan peserta didik masih tergolong kategori kurang. Keaktifan peserta didik memenuhi kriteria baik jika presentase keaktifannya diatas $70 \%$. Oleh karena itu peneliti melanjutkan penelitiannya ke siklus berikutnya.

\section{Siklus II}

Siklus II dilaksanakan pada hari Jum'at, 13 November 2020 di kelas XI IPS SMA Negeri 2 Kroya dengan jumlah peserta didik sebanyak 24. Materi yang disampaikan pada siklus II adalah sifat stratifikasi social. Sama dengan ketika siklus I, langkahlangkah dalam siklus II dimulai dari perencanaan, pelaksanaan, pengamatan dan refleksi. Hasil dari siklus II adalah sebagai berikut 


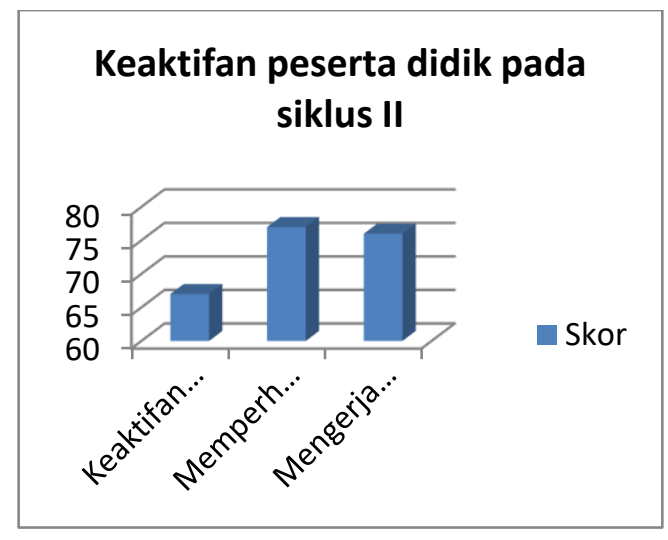

Data tersebut dapat kita jabarkan menjadi :

\begin{tabular}{|l|l|c|}
\hline No & \multicolumn{1}{|c|}{ Aspek yang diamati } & Score \\
\hline 1 & $\begin{array}{l}\text { Keaktifan menanya dan } \\
\text { menyampaikan pendapat }\end{array}$ & 67 \\
\hline 2 & $\begin{array}{l}\text { Memperhatikan apa yang } \\
\text { disampaikan guru }\end{array}$ & 77 \\
\hline 3 & $\begin{array}{l}\text { Mengerjakan tugas dengan } \\
\text { kemampuan sendiri }\end{array}$ & 76 \\
\hline & Jumlah scor yang muncul & 220 \\
\hline
\end{tabular}

\begin{tabular}{|l|c|c|c|}
\hline Tahapan & $\begin{array}{c}\text { Pra } \\
\text { Siklus }\end{array}$ & Siklus I & $\begin{array}{c}\text { Siklus } \\
\text { II }\end{array}$ \\
\hline $\begin{array}{l}\text { Keaktifan } \\
\text { peserta } \\
\text { didik }\end{array}$ & 55,95 & 64,06 & 76,39 \\
\hline \multicolumn{4}{|c|}{ Dari 24 peserta didik, yang }
\end{tabular}

mengikuti pembelajaran sebanyak 24 anak. Ini berarti bahwa pembelajaran hari ini diikuti oleh semua peserta didik kelas XI IPS SMA Negeri 2 Kroya. Jumlah maksimal indicator adalah 3 indikator x 4 (skor maksimal) x 24 peserta didik $=288$

Dari tabel diatas, terdapat sebanyak 220 indikator yang muncul dari 288, sehingga dapat dihitung persentase keaktifan peserta didik sebagai berikut :

Keaktifan peserta didik $=\frac{\text { jumlah indikator yang muncul }}{\text { jumlah maksimal indikator }} \times 100 \%$ Keaktifan peserta didik $=\frac{220}{288} \times 100 \%$ Keaktifan peserta didik $=76,38 \%$

Dari perhitungan diatas, kita dapat melihat bahwa pada siklus II persentase keaktifan peserta didik sebesar 76,38\%. Hal ini menunjukkan keaktifan belajar peserta didik mengalami peningkatan dibandingkan dengan keaktifan belajar ketika pembelajaran sebelumnya yaitu sebesar $64,06 \% \%$.

\section{Perbandingan hasil pengamatan} pada tindakan pra siklus, siklus I dan siklus II

Perbandingan tingkat keaktifan belajar peserta didik pada kegiatan pra siklus, siklus I dan siklus II

Berdasarkan angka yang ditunjukkan dalam table, kita dapat melihat terjadi peningkatan prosentase keaktifan peserta didik mulai dari pra siklus, siklus I dan siklus II. Maka, tujuan dari penelitian tindakan kelas ini sudah tercapai sesuai dengan harapan peneliti. 


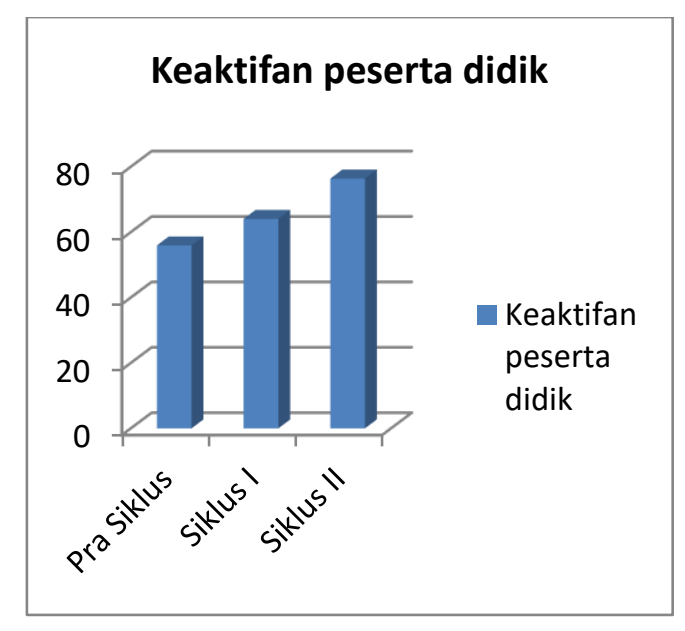

\section{Diskusi}

Berdasarkan grafik diatas, dapat disimpulkan bahwa capaian dari keaktifan belajar peserta didik semakin meningkat dan memenuhi indicator keberhasilan keaktifan belajar setelah diterapkannya model pembelajaran discovery learning. Hal ini sesuai dengan salah satu point yang diungkapkan oleh Saefuddin dan Ika Budiarti (2014: 57-58) yang menyebutkan bahwa Model Pembelajaran Discovery Learning memiliki kelebihan dan kekurangan diantaranya adalah “ (7) Berpusat pada peserta didik dan guru berperan sama-sama aktif mengeluarkan gagasan-gagasan. Bahkan guru dapat bertindak sebagai peserta didik dan sebagai peneliti di dalam situasi diskusi".

Berdasarkan kelebihan tersebut pada point (7), dijelaskan bahwa model pembelajaran berpusat pada peserta didik dan guru berperan sama-sama aktif mengeluarkan gagasangagasannya. Bahkan guru dapat bertindak sebagai peserta didik dan sebagai peneliti di dalam situasi diskusi. Sehingga keaktifan belajar dari peserta didik dapat dimaksimalkan sesuai dengan prinsip dari kurikulum 2013 yang memposisikan peserta didik sebagai pusat pembelajaran (student center). Dengan demikian model pembelajaran discovery learning terbukti dan dapat digunakan sebagai salah satu alternative untuk meningkatkan keaktifan belajar peserta didik.

\section{Kesimpulan}

Berdasarkan hasil penelitian dan pembahasan, dapat diambil kesimpulan bahwa dengan diterapkannya model pembelajaran discovery learning dapat meningkatkan keaktifan belajar peserta didik kelas XI IPS SMA Negeri 2 Kroya. Hal ini dibuktikan dengan meningkatnya persentase dari keaktifan belajar peserta didik hingga mencapai indicator keberhasilan yang telah ditentukan sebelumnya yaitu sebesar $70 \%$.

Pada pra siklus, persentase keaktifan belajar peserta didik hanya sebesar $55,95 \%$. Kemudian pada siklus I persentase keaktifan belajar peserta didik mengalami peningkatan hingga 
64,06\%. Hasil tersebut meningkat lagi

$76,38 \%$.

ketika dilakukan siklus II menjadi

\section{Daftar Pustaka}

A.M. Sardiman. 2011. InteraksidanMotifasiBelajar. Jakarta: PT RajagrafindoPersada.

Arikunto, Suharsimi. 2010. Prosedur Penelitian suatu Pendekatan Praktik Edisi Revisi 2010. Jakarta: PT Rineka Cipta.

Dimyati \& Mudjiono. 2009. Belajar dan Pembelajaran. Jakarta: PT Rineka Cipta.

Rusman. 2014. Model-model Pembelajaran. Jakarta: PT Rajagrafindo Persada.

Saefuddin, A. \& Berdiati, I. 2014. Pembelajaran Efektif, Bandung: PT Remaja Rosdakarya. 